\title{
Therapeutic Potential of Calotropis procera: A giant milkweed
}

\author{
Rohit Sharma ${ }^{1,2}$, Gulab S. Thakur ${ }^{2}$, Bhagwan S. Sanodiya ${ }^{2}$, Ashish Savita ${ }^{2}$, \\ Mukeshwar Pandey ${ }^{3}$, Anjana Sharma ${ }^{1}$ and Prakash S. Bisen ${ }^{1,2,4}$ \\ $I^{*}$ (Department of Post Graduate Studies and Research in Biological Sciences, Rani Durgavati Vishwavidyalaya, \\ Jabalpur - 482004, India) \\ ${ }^{2}$ (Plant Biotechnology Laboratory, R\&D Division, Tropolite Foods Pvt Ltd, Davars Campus, Tansen Road, \\ Gwalior- 474002, India) \\ ${ }^{3}$ (Xcelris Genomics, Old Prem Chand Nagar Road, Opp Satyagarh Chhavani, Bodakdev, Ahmedabad-380054, \\ India) \\ ${ }^{41}$ Defence Research Development Establishment, Defence Research Development Organization, Ministry of \\ Defence, Govt. of India, Jhansi Road, Gwalior 474002, India)
}

\begin{abstract}
Medicinal plants are the local heritage with global importance playing a vital role in world health care system of developing countries. Calotropis procera (Asclepiadaceae), a giant milk weed, is known for its pharmacological importance for centuries. The coarse shrub is a very promising source of anticancerous, ascaricidal, schizonticidal, anti-microbial, anthelmintic, insecticidal, anti-inflammatory, anti-diarrhoeal, larvicidal with many other beneficial properties. Plant is described as a golden gift for human kind containing calotropin, calotropagenin, calotoxin, calactin, uscharin, amyrin, amyrin esters, uscharidin, coroglaucigenin, frugoside, corotoxigenin, calotropagenin and voruscharine used in many therapeutic applications. Different compounds like norditerpenic esters, organic carbonates, the cysteine protease procerain, alkaloids, flavonoids, sterols and numerous cardenolides made this plant of scientific attraction for centuries. Plant is not only a great source of natural hydrocarbons but also contains several metabolites used as folk medicine for the treatment of leprosy, elephantiasis, fever, menorrhagia, malaria and snake bite. The review discusses the potential of Calotropis procera in health care management.
\end{abstract}

Keywords: anticancer, antimicrobial, biosorbent, Calotropin, ethnomedicine

\section{Introduction}

The human race started using plants/and or plant products successfully as a mean of treatment of diseases and injuries as effective therapeutic tools from the early days of civilization to modern age [1,2]. Calotropis procera Linn. (Asclepiadaceae) locally known as "aak" in India and is commonly known as "Sodom apple" or "Usher" (Swallow wort in English and Akundia in Hindi) is well known for its high medicinal properties. It is a xerophytic, erect shrub about $6 \mathrm{~m}$ high, growing widely throughout the tropic of Africa and Asia [3]. It is grown abundantly in arid and semi-arid regions without irrigation, chemical fertilizers, pesticides or other agronomic practices. Plant is a useful bio-indicator to monitor pollution in varying concentrations of $\mathrm{Br}$, $\mathrm{Mn}, \mathrm{Se}, \mathrm{Cr}$ and $\mathrm{Zn}$ between urban and suburban samples [4]. For centuries, the coarse shrub of $C$. procera is known as a very promising source of ascaricidal [5], schizonticidal, nematocidal [6,7], anti-microbial [8], antihelmintic, molluscicidal [9], insecticidal, anti-inflammatory, anti-diarrhoeal, larvicidal [10-13], anticancer $[14,15]$, cytotoxic chemicals and many other beneficial properties make this plant as a golden gift for human kind [16].

The leaf biomass of the plant is potentially a good adsorbent for the removal of crystal violet (a cationic dye) from aqueous solution and is being used in textile industry [17]. The giant milk weed is an important source for plant hydrocarbons [18] used for testing various drugs against anti-inflammatory and antinociceptive activity [19-23]. Present review discusses the biopharmaceutical prospective future potential of Calotropis procera Linn.

\section{Phytochemical Constituents And Principle Active Compounds}

Pharmacologically substances such as calotropon [Fig. 1 (I)], calotropin [Fig. 1 (II)], uscharine [Fig. 2 (III)], calotoxin [Fig. 2 (IV)], calctin [Fig. 2 (V)], uscharidin [Fig. 3 (VI)] and calotropagenin [Fig. 4 (X)] etc. are some important chemicals obtained from the leaves and latex of $C$. procera plant [24] [Table-1]. The phytochemical studies on the aerial parts of the plant showed the presence of alkaloids, cardiac glycosides, tannins, flavonoids, sterols and/or triterpenes [25]. Earlier pentacyclic triterpenes [26-29], alkaloids, cardenolides [30], phytosterols [31], and triterpenoids saponins have been isolated from the roots of $C$. procera. Fatty acid composition in the extract of $C$. procera was analyzed which has 7 saturated and 11 unsaturated fatty 
acids [32]. The essential elements $\mathrm{Al}, \mathrm{As}, \mathrm{Cu}, \mathrm{Ca}, \mathrm{Cr}, \mathrm{Cd}, \mathrm{Fe}, \mathrm{K}, \mathrm{Mn}, \mathrm{Na}, \mathrm{Pb}$, and $\mathrm{Zn}$ have been reported from this medicinal plant in variable range with $27-32 \%$ total protein.

Calotropin, uscharin, calotoxin, calctin, amyrin, amyrin esters, uscharidin, calotoxin were isolated from the leaves and stalks of $C$. procera and $C$. gigantae [33-35]. The chemical constituents of the seeds of $C$. procera were investigated and reported the occurrence of coroglaucigenin [Fig. 3 (VII)], frugoside, corotoxigenin [Fig. 3 (VIII)], and calotropin [36]. Besides uscharine another cardenolide namely voruscharine [Fig. 4 (IX)] was identified in the latex of $C$. procera [37]. The constitution of calotropagenin [Fig. $4(\mathbf{X})$ ] and voruscharine were determined and reported [37-39]. Pyrocatechuic acid [Fig. 4 (XI)] $\alpha$ - amyrin, $\beta$-amyrin, taraxasterol, $\psi$-taraxastrol, $\beta$-sitosterol, taraxasteryl acetate, taraxasteryl bebzoate, $\alpha$ - amyrin benzoate, $\beta$-amyrin benzoate, $B$-amyrin acetate, acetic acid and isovaleric acid, taraxasterol isovalerate, benzoyllineolone [Fig. 5 (XII)] and benzoylisolineolane [Fig.5 (XIII)] were isolated from the root bark, leaf and latex of $C$. procera [40, 41]. Uzarigenin [Fig. 6 (XIV)], syrigenin [Fig. 6 (XV)] and proceroside [Fig. 6(XVI)] were also isolated from the latex of $C$. procera [43]. The presence of D-glucose, D-arabinose, D-glucosamine and $\alpha$-rhamnose in the aqueous extract of the leaves of $C$. procera were reported [44] while $\alpha$ - and $\beta$-amyrin and $\beta$-sitosterol were identified in the unsaponifiable matter of the petroleum ether extract of same species [45]. Calotropin, calotoxin, uscharine, uscharidin and choline [Fig. 7 (XVII)] were also isolated from the latex of C. procera.

Calotropenyl acetate [Fig. 7 (XVIII)] and procesterol [Fig. 7 (XIX)] were isolated from the flowers of C. procera $[29,31]$. The presence of lupeol, $\beta$ - amyrin, $\alpha$ - and $\beta$ - calotropeol and 3 -epimoretenol were reported in the latex of C. procera [46] while in the following year multiflorenol, [Fig. 8 (XX)] cyclosadol, [Fig. 8 (XXI)] cyloart-23-ene-3ß, 25-diol, $\beta$-sitostenone, [Fig. 8 (XXII)] $\alpha$ - and $\beta$-amyrin, stigmasterol and $\beta$ sitosterol, procerain were identified in the flowers, latex and leaves of the same species [47, 48].Alkaloids, flavonoids, tannins, steroids, triterpenoids, saponins and saponin glycosides were detected in the leaves and root extract fractions [49], with only flavonoids, triterpenoids and saponins in the stem bark extracts. The results obtained lend scientific credence for the use of the plant against fungal diseases. Two flavonol glycosides were isolated and identified from the leaves of $C$. procera $[50,51]$. There is hardly any doubt that $C$. procera is a recommended natural source of phytochemicals having a good sign for future biopharmaceutical prospect.

\section{Ethanomedicinal Aspects}

Medicinal plants have remained the major source of both orthodox and traditional medicine worldwide. Accordingly, attention of scientists and researchers have been attracted towards developing new antibiotics that will curtail the increasing drug resistance among microorganisms [52]. An infusion of bark powder of $C$. procera (Giant milkweed) is used to treat leprosy and elephantiasis [53]. The tissues, especially the root bark, are used to treat a variety of illness including leprosy, fever, menorrhagia, malaria, and snake bite [54]. Extracts, chopped leaves, and latex have shown great promise as nematicides, in vitro and in vivo $[55,56]$. Local administration of the latex has been reported to elicit an inflammatory response that is mediated through histamine and prostaglandins $[21,22,57,58]$. It has been reported that the latex exhibit potent antiinflammatory, antidiarrheal, analgesic, antipyretic and schizonticidal activities [59-63]. Plants used for traditional medicine generally contain a number of compounds which may be a potential natural antimicrobial combination and which may serve as an alternative, effective, cheap and safe antimicrobial agents for treatment of common microbial infections.

C. procera showed adversely affects early and late pregnancy in rats [64]. A recent survey of different regions of the Kingdom of Saudi Arabia showed that roots and aerial parts of the giant milk weed are commonly used in traditional medicine for the treatment of variety of diseases including constipation, fever, joint pain and muscular spasm. Latex proteins from the plant are partially digested upon in vitro enzymatic action and are not immunologically detected in fecal material as found in Wistar rats [65]. It was reported that C. procera used in traditional medicine as a purgative, anthelmintic, anticoagulant, anticancer as well as antipyretic, analgesic, antimicrobial and antiseptic for skin infection [66,67]. The root of the giant milk weed is used as a carminative in the treatment of dyspepsia and also used by various tribes of central India as a curative agent for jaundice [68, 69].

\section{PHARMACOLOGICAL ASPECT}

Medicinal plants and their values play an important role in health care system of developing countries. There is always an increase emphasis on primary health care: basic health care which is not only effective, but affordable by under-equipped and under-financed countries and by poor communities within those countries. It is expected that this plant could benefit the upcoming needs of the population looking to various pharmacological aspects, in future. The different pharmacological properties of C. procera are shown in [Fig.-9].

\section{ANTI-CANCEROUS ACTIVITY}


The incidence of cancer is increasing worldwide and it is the single most common cause of deaths in both developed and developing countries [70, 71]. However, in view of the side effects of drugs used in the chemotherapy of different cancers, traditional herbal medicine and complementary and alternative medicine (CAM) are increasingly becoming popular among cancer patients in the developed countries [72, 73]. The root extract of $C$. procera has been found to produce a strong cytotoxic effect on COLO 320 tumor cells. The anticancer property of the dried latex (DL) of $C$. procera was evaluated in the X15-myc transgenic mouse model of hepatocellular carcinoma and elucidated its mechanism of action in cell culture. DL treatment of mice showed a complete protection against hepatocarcinogenesis. The serum VEGF (Vascular endothelial growth factor) level was significantly lowered in the treated mice as compared to control animals. Cell culture studies revealed that the methanolic extract of DL as well as its fraction 8 induced extensive cell death in both Huh-7 (hepatoma cells) and COS-1 (non-hepatoma cells) while AML12 (non transformed hepatocytes cells) were spared. This was accompanied by extensive fragmentation of DNA in Huh-7 and COS-1 cells. No change in the levels of canonical markers of apoptosis such as Bcl2 and caspase 3 was observed [14, 15].

The protein fraction of the latex (LP) was evaluated to determine its potential cytotoxic activity against human cancer cell line MCF-7. The cell line MCF-7 (breast) was treated with increasing concentrations of LP for 24h and analyzed by the MTT assay. A decrease of cell growth was detected in the presence of LP and values of $\mathrm{IC}_{50}$ obtained after $24 \mathrm{~h}$ of exposure for LP was $88.33 \mu \mathrm{g} / \mathrm{ml}$. It has been suggested in the literature that the cytotoxic activity of LP is due, partly, the inhibition of the synthesis of DNA. The in vitro cytotoxic activity of laticifer proteins (LP) recovered from the latex of $C$. procera was evaluated [74]. The LP displayed considerable cytotoxicity with $\mathrm{IC}_{50}$ values ranging from 0.42 to $1.36 \mu \mathrm{g} / \mathrm{ml}$ to SF295 and MDA-MB-435 cell lines, respectively. The result suggested that LP is a target for DNA topoisomerase-I triggering apoptosis in cancer cell lines. The cytotoxic and anti-mitotic potential of latex of $C$. procera by standard assay method was evaluated using Allium cepa root meristem model, the effect was compared with standard anticancer drug cyclophosphamide and non-cytotoxic drugs cyproheptadine and aspirin. DL (dried latex) significantly inhibited the growth of roots and mitotic activity in a dose-dependent manner [75, 76].

Anti-tumor studies with extracts of $C$. procera root employing Hep2 cancer cells and their possible mechanism of action was observed, results indicated that the root extracts of the plant inhibited the proliferation of Hep2 cancer cells via apoptotic and cell cycle disruption based mechanisms [77]. Recently the cardiotonic steroid UNBS1450 (derived from 2-oxovoruscharin) from C. procera was shown to additionally exert an anticancer activity. UNBS1450 has been proven to be a potent sodium pump inhibitor, showing anti-proliferative and cell death-inducing activities. This anti-cancer potential of UNBS1450 is achieved by disorganization of the actin cytoskeleton after binding to the sodium pump at the cellular membrane, by inducing autophagy-related cell death, by repressing NF-KB activation as well as by down-regulating c-Myc in cancer cells [77].

\section{Anti-Inflammatory Activity}

The latex of the plant $C$. procera has been reported to exhibit potent anti-inflammatory activity against carrageenin and formalin that are known to release various mediators. The efficacy of extracts prepared from the latex of $C$ procera against inflammation induced by histamine, serotonin, compound 48/80, bradykinin (BK), and prostaglandin E2 (PGE2) in the rat paw oedema model was evaluated [78]. The anti-inflammatory effect of aqueous and methanolic extracts of DL was more pronounced than phenylbutazone (PBZ) against carrageenin while it was comparable to chlorpheniramine and PBZ against histamine and PGE2, respectively. Both extracts produced about $80 \%, 40 \%$, and $30 \%$ inhibition of inflammation induced by BK, compound 48/80, and serotonin. The histological analysis revealed that the extracts were more potent than PBZ in inhibiting cellular infiltration and subcutaneous oedema induced by carrageenin. The extracts of DL exert their anti-inflammatory effects mainly by inhibiting histamine and BK and partly by inhibiting PGE2.

The anti-inflammatory property of the latex of $C$. procera was studied on carrageenan- and formalininduced rat paw oedema model [60]. A single dose of the aqueous suspension of the dried latex was effective to a significant level against the acute inflammatory response. The crude dry latex of $C$. procera possesses a potent anti-inflammatory activity [79]. The anti-inflammatory activity of petroleum ether, acetone, methanol and aqueous extracts of dry latex of the plant were tested in the carrageenan induced rat paw oedema model. All the fractions exhibited anti-inflammatory activity but inhibition of oedema was found to be greatest with the acetone and aqueous extracts.

The latex is as potent as standard anti-inflammatory drug phenylbutazone (PBZ) in inhibiting inflammatory response induced by various inflammagens in acute and chronic models of inflammation [80], oral administration of DL significantly inhibited oedema formation induced by carrageenan and Freund's adjuvant. It also inhibited granuloma formation induced by cotton pellet and carrageenan. DL significantly inhibited fluid exudation, possibly due to its effect on vascular permeability. Besides, it also delayed the onset and intensity of UV induced erythema. In all these models, the anti-inflammatory activity of DL was comparable to standard anti-inflammatory drugs. Interleukin-1 $\beta$ (IL-1 $\beta$ ), a pro-inflammatory cytokine, has been reported to exhibit anti- 
inflammatory properties in the carrageenan-induced paw oedema model. For the protection against inflammation and oxidative stress taking methanolic extract of dried latex (MeDL) on the levels of prostaglandins $\left(\mathrm{PGE}_{2}\right)$, tumor necrosis factor (TNF- $\alpha$ ), nitric oxide (NO), myeloperoxidase (MPO), oxidative stress parameters, and joint histology in Freund's Complete Adjuvant (FCA)-induced monoarthritis in rats was evaluated [81]. The effect of MeDL was compared with rofecoxib, a selective COX-2 (cyclooxygenase-2) inhibitor, and phenylbutazone (PBZ) a nonselective COX inhibitor. The result obtained was satisfactory because $\mathrm{MeDL}$ of $C$. procera markedly reduces cell influx, release of mediators, and oxidative stress associated with arthritic condition, and therefore has the potential to be used as an anti-arthritic agent.

\section{Larvicidal Activity}

Commonly mosquitoes proliferate abundantly in Africa, Latin America, North-eastern Brazil as well as in natural areas like the Amazon Region. In early 1980s a brief communication pointed out the whole latex of $C$. procera as a suitable source of active compounds exhibiting larvicidal activity [10]. They act as vector of endemic diseases such as yellow fever in the Amazon Region and dengue hemorrhagic fever in many regions of America, South East Asia, the Pacific islands area, and Africa [82]. The mosquito Aedes aegypti is the vehicle of transmission of theses infirmities, can be found disseminated everywhere within these areas and this contributes to aggravate the morbidity statistics. As attempts to control the drastic effects on public health the strategies include massive dissemination of expensive commercial pesticides into air and personal training visiting people in loci, which in turn is time-consuming. Thus, it would be of great relevance to search for alternatives to improve the effectiveness of combating and preventing the proliferation of Ae. aegypti as well as other important mosquitoes involved in disease transmission to people and animal. Many sources of natural compounds have been suggested as alternatives for conventional chemical control [83]. C. procera was tested against Anopheles labranchiae mosquito larvae and exhibited high larvicidal activity with $\mathrm{LC}_{50}(24 \mathrm{~h})$ ranging from 28 to $325 \mathrm{ppm}$ [84].

The giant milk weed was effective in both inhibition of feeding and causing mortality of larvae. The effect of several commercial and locally extracted biorational pesticides was showed which included $C$. procera against the Egyptian alfalfa weevil (EAW) and Hypera brunneipennis (Boheman) [85]. The present review had now extended the work done by various researchers and reported the effect of different rubber-free fractions of the latex upon egg hatching and larval development of the mosquito Ae. aegypti. Latex constituents from $C$. procera display toxicity upon egg hatching and larvae of Ae. aegypti [65]. The whole latex was shown to cause $100 \%$ mortality of $3 \mathrm{rd}$ instars within $5 \mathrm{~min}$. It was fractionated into water-soluble dialyzable (DF) and nondialyzable (NDF) rubber-free materials. It may be possible that the highly toxic effects of the whole latex from C. procera upon egg hatching and larvae development should be at least in part due to its protein content found in NDF. However, the toxicity seems also to involve non protein molecules present in DF.

The different water concentrations of this biocide which have brought forward very important observations on the ovipositioning behaviour of Aedes aegypti was evaluated [86]. At $0.7 \%$ concentration of latex, the ovipositioning was avoided by the gravid female mosquitoes and this behaviour continued till three gonotrophic cycles. However, at lower concentrations $(0.2 \%$ and $0.1 \%)$ of the larvicidal latex, the refractory behaviour of ovipositioning could not be retained up to the third gonotrophic cycle. The concentration of the latex such as $0.7 \%$ and $0.2 \%$ were observed as ovicidal also and this effect continued across all the gonotrophic cycles. The behavioural observations reported may serve as significant information on choosing bio-larvicides for vector control against dengue. The latex of $C$. procera has shown larvicidal efficacy against all three important vector species viz, Ae. aegypti, An. stephensi and Cx. quinqefaciatus, vectors of dengue, malaria and Lymphatic filariasis respectively. The effects of alkaloid extracts of $C$. procera leaves at the vegetative stage on survival of fifth instar larvae and on ovarian growth of Schistocerca gregaria have been studied. The results revealed that a mortality rate of $100 \%$ was reached in the hoppers on the 15th day after the beginning of the treatment [87]. Insecticidal potentialities of aqueous extracts from C. procera against Henosepilachna elaterii were evaluated by two methods of extraction [88]. The shaker aqueous extract of leaf, flower and roots of the plant proved most effective in the control of Henosepilachna elaterii as a strong repellent and thus deterred the insects from feeding. Soxhlet extract had no anti-insect activity. The toxic effects of crude extracts (both for leaves and flowers) of C. procera against two species of termites i.e. Heterotermes indicola and Coptotermes heimi were studied [89]. Toxic effects of both extracts (leaves and flowers) were more profound against the Coptotermes heimi than Heterotermes indicola during feeding stage. Also the flower extracts caused more mortality than the leaves for both species suggesting the availability of high contents of toxic materials in flowers. Similarly, C. procera showed moderate larvicidal effects against second and fourth instar larvae of the laboratory-reared mosquito species, Culex quinquefasciatus, in which the major lymphatic filariasis was used [90]. C. procera appears to be more effective than $H$. recurvum and $A$. indica in the sense that crude extract 
application on sugarcane sets and then mixing whole plants of $C$. procera into the soil did not allow the termites to forage in large number [91].

\section{Anti-Microbial Activity}

It is well known that infectious diseases account for high proportion of health problems, especially in the developing countries. Microorganisms have developed resistance to many antibiotics, and this has created immense clinical problem in the treatment of infectious diseases [92]. This resistance has increased due to indiscriminate use of commercial antimicrobial drugs commonly used in the treatment of infectious diseases. This situation forced scientists to search for new antimicrobial substances from various sources, such as medicinal plants [93]. Antimicrobials of plant origin are efficient in the treatment of infectious diseases mitigating simultaneously many of the side effects that are often associated with synthetic antimicrobials. The antimicrobial activities of plant oils and extracts have formed the basis of many applications, including raw and processed food preservation, pharmaceuticals, alternative medicine and natural therapies [94]. The antimicrobial activity of the leaf extracts of $C$. procera was evaluated and the inhibitory effect of extract of latex of C. procera against Candida albicans was also observed [95, 96].

Moreover, the increasing use of plant extracts in the food, cosmetic and pharmaceutical industries suggests that in order to find active compounds, a systematic study of medicinal plants is very important [97]. The anti-bacterial activity of a new cardenolide, 7B, 14B-dihydroxy-5-card-20(22) enolide (proceragenin) of $C$. procera was evaluated [98] which has been found to be active against Pseudomonas pseudomallei, a causative agent of melioidosis. The antimicrobial activity of the giant milk weed was also showed [66]. The anti-fungal activity was screened (agar dilution method) using organic solvent extracts of the stem bark of C. procera [49], which significantly $(\mathrm{p}<0.05)$ inhibited growth of Trichophyton rubrum and Microsporum gypseum. All the leaf extract fractions completely inhibited the growth of the tested organisms. The root fractions of hexane (HX) and petroleum ether $(\mathrm{PE})$ extracts showed significant $(\mathrm{p}<0.05)$ growth inhibitions of Microsporum gypseum and Aspergillus niger. All the aqueous extract fractions of the plant parts showed complete growth inhibition of all the tested organisms. The antimicrobial activity was evaluated against some of the tested microorganisms (pathogenic bacteria, Staphylococcus aureus and Pseudomonas aeruginosa, and one pathogenic fungus, Candida albicans) from the extracts of Calotropis procera [99]. The antifungal activities of aqueous extract of Calotropis procera was determined against Epidermophyton flocosum and Tricophyton gypseum using agar diffusion techniques [100]. The crude extract of $C$. procera showed activity on E. flocosum and T. gypseum at $4.0 \mathrm{mg} / \mathrm{ml}$. The result of minimum inhibitory concentration (MIC) was 0.5 and $0.9 \mathrm{mg} / \mathrm{ml}$ and that of minimum fungicidal concentration (MFC) were 2.0 and $4.0 \mathrm{mg} / \mathrm{ml}$, respectively. The result of the Ames test indicated that the crude extract is not mutagenic. The results of the study suggest that $C$. procera stem could be a potential source of chemotherapeutic drugs for the treatment of tinea associated with E. flocosum and T. gypseum. The $n$ butanol extract of Calotropis procera flowers proved to be the most effective against the tested bacterium [101]. The aqueous and organic solvents (hexane and petroleum ether) extracts of leaves, stem barks and roots of $C$. procera were screened for antifungal (agar dilution method) property [102], organic solvents extracts of the stem bark significantly $(\mathrm{p}<0.05)$ inhibited growth of Trichophyton rubrum and Microsporum gypseum. The root fractions of hexane $(\mathrm{HX})$ and petroleum ether $(\mathrm{PE})$ extracts showed significant $(\mathrm{p}<0.05)$ growth inhibition of Microsporum gypseum and Aspergillus niger.

The antimicrobial effect of ethanol, aqueous and chloroform extracts of leaf and latex of C. procera were studied on five bacteria namely, Escherichia coli, Staphylococcus aureus, Staphylococcus albus, Streptococcus pyogenes, Streptococcus pneumoniae and three fungi: Aspergillus niger, Aspergillus flavus, Microsporium boulardii and one yeast Candida albicans using agar well diffusion and paper disk methods [103]. The results revealed that ethanol was the best extractive solvent for antimicrobial properties of leaf and latex of $C$. procera followed in order by chloroform and aqueous $(\mathrm{P}<0.05)$. The ethanolic extracts of $C$. procera latex gave the widest zone of inhibition $(14.1 \mathrm{~mm})$ against E.coli using agar well diffusion while $9.0 \mathrm{~mm}$ was recorded for the same organism in the disc plate method. The growth of six bacterial isolates was inhibited by the three extracts except $P$. aeruginosa and $S$. pyogenes that were not inhibited by the aqueous extracts of both leaf and latex of C.procera. Similarly, the growth of four test fungi were inhibited by ethanol and chloroform extracts while the aqueous extract was the least effective on the test fungi. The best antifungal activity was recorded in ethanol extract of C.procera latex against Candida albicans. The minimum inhibitory concentration (MIC) for the ethanol extract was between 5.0 and $20.0 \mathrm{mg} / \mathrm{ml}$ for fungi. The study revealed that the C. procera latex demonstrated strong inhibitory effect on the test organisms than its leaf. The results therefore established a good support for the use of this plant in traditional medicine. All the research mentioned definitely shed the light on the antimicrobial ability of extracts from $C$. procera, which lend scientific credence for the use as a natural antimicrobial agents in pharmaceutical and food preservation systems in future. 


\section{Anti-Diarrhoeal Activity}

The dry latex (DL) of C. procera was evaluated for the anti-diarrhoeal activity [61]. Like atropine and phenylbutazone (PBZ), a single oral dose of DL $(500 \mathrm{mg} / \mathrm{kg}$ ) produced a significant decrease in frequency of defecation, severity of diarrhoea and afforded protection from diarrhoea in $80 \%$ rats treated with castor oil. DL produced a decrease in intestinal transit (27-37\%) as compared to both normal and castor oil treated animals. Unlike atropine, DL significantly inhibited castor oil induced enteropooling. However, it did not alter the electrolyte concentration in the intestinal fluid as compared to castor oil treated rats.

\section{Anthelmintic Activity}

The antihelmintic activity using adult earthworms from the crude latex of $C$. procera was evaluated [57]. Both fresh as well as aqueous extracts of dried latex exhibited a dose-dependent inhibition of spontaneous motility (paralysis) and evoked responses to pin-prick. With higher doses $(100 \mathrm{mg} / \mathrm{ml}$ of aqueous extract of dry latex and $100 \%$ fresh latex), the effects were comparable with $3 \%$ piperazine. However, there was no final recovery in the case of worms treated with latex in contrast to piperazine with which the paralysis was reversible and the worms recovered completely within six hours. The results showed that latex possesses wormicidal activity and thus, may be useful as an anthelmintic. The anthelmintic activity of $C$. procera latex in sheep was investigated [104] that had been infected with single oral doses of 12000 infective Haemonchus contortus larvae. Inappetence, dullness, erosive abomasitis, decreased haemoglobin concentration and increased eosinophils were the main features of haemonchosis in the sheep. In the sheep treated with single oral doses of $0.01 \mathrm{ml}$ or $0.02 \mathrm{ml} / \mathrm{kg}$ body weight of C. procera latex, egg production was significantly reduced, but not completely suppressed, and fewer adult Haemonchus worms were found in the abomasum. Although the appetite improved, the haemoglobin concentration and serum copper, iron and zinc levels were still reduced after therapy with Calotropis latex. Calotropis latex showed a concentration-dependent larvicidal activity in vitro within 20 min of application.

The anthelmintic activity of $C$. procera flowers in comparison with levamisole was evaluated through in vitro and in vivo studies [105]. In vitro studies revealed anthelmintic effects $(P<0.05)$ of crude aqueous (CAE) and crude methanolic extracts (CME) of $C$. procera flowers on live Haemonchus contortus as evident from their mortality or temporary paralysis. For in vivo studies, its flowers were administered as crude powder (CP), CAE and CME to sheep naturally infected with mixed species of gastrointestinal nematodes. Egg count percent reduction (ECR) was recorded as 88.4 and $77.8 \%$ in sheep treated with $\mathrm{CAE}$ and $\mathrm{CP}$ at $3 \mathrm{~g} \mathrm{~kg}^{-1}$ body weight on day 7 and 10 post-treatment (PT), respectively. CME was least effective resulting in 20.9\% reduction in ECR on day 7 PT. It was found that $C$. procera flowers possess good anthelmintic activity against nematodes, yet it was lower than that exhibited by levamisole (97.8-100\%). It is suggested that further research on large scale should be carried out involving a large number of animals, doses higher than those used in the current study, identification of active principles, and standardization of dose and toxicity studies for drug development.

\section{Spasmolytic Activity}

Spasmolytic is referred as a muscle relaxant, is a drug which affects skeletal muscle function and decreases the muscle tone. It may be used to alleviate symptoms such as muscle spasms, pain, and hyperreflexia. The aqueous extract of $C$. procera was evaluated for its spasmolytic effect using in vitro trachea smooth muscle chain of Guinea-pig. The extract (50, 100 and $200 \mu \mathrm{g} / \mathrm{ml})$ showed a dose-dependent relaxant activity probably exhibited through the direct relaxant action on the smooth muscle [106].

\section{Immunomodulatory Activity}

The ability of $C$. procera to activate macrophages-effector cells in inflammatory and immune responses was investigated [107]. Intraperitoneal injection of $C$. procera extract (CPE) in mice (2 mg/mouse) induced migration of macrophages to the intraperitoneal cavity, confirming the pro-inflammatory effects of watersoluble CPE. The direct effects of CPE on macrophages were then assessed by measuring the production of nitric oxide (NO) as an indicator for macrophage activation. Addition of CPE (1-10 $\mu \mathrm{g} / \mathrm{ml})$ to the culture medium of the murine monocyte/macrophage cell line RAW264.7 caused an increase in NO production in a time- and dose-dependent manner. CPE-elicited NO production was blocked by application of an inhibitor of inducible nitric oxide synthase (iNOS). Expression of iNOS mRNA was induced by treatment of cultured macrophages with CPE. Injection of CPE in mice also resulted in an increase in plasma NO level. The results thus suggested that CPE activates macrophages and facilitates NO production via up-regulation of iNOS gene expression. 


\section{Anti-Pyretic Activity}

Antipyretic effect from aerial parts of $C$. procera was reported [25]. Similarly, the ethanolic extract of C. procera latex to possess antipyretic effect against yeast induced fever in rats was also reported [108], four hours after administration of yeast, either dose of DL (250 or $500 \mathrm{mg} / \mathrm{kg})$, aspirin $(200 \mathrm{mg} / \mathrm{kg})$ or saline were administered orally in $1 \mathrm{ml}$ volume. Body temperature $\left({ }^{\circ} \mathrm{F}\right)$ was measured at $0,3,4$ and 6 hours through rectal route using a digital thermometer. Administration of yeast produced an increase in rectal temperature from $97.32 \pm 0.19^{\circ} \mathrm{F}$ which reached to its maximum in $4 \mathrm{~h}\left(100.0 \pm 20.27^{\circ} \mathrm{F}\right)$. There was no further rise in temperature at $6 \mathrm{~h}$ in the control group and the mean temperature remained at $99.74 \pm 0.15^{\circ} \mathrm{F}$. Administration of DL-250 mg/kg and $500 \mathrm{mg} / \mathrm{kg}$ at $4 \mathrm{~h}$ produced a significant $(\mathrm{P}<0.05)$ decline in rectal temperature to $98.50 \pm 0.29^{\circ} \mathrm{F}$ and $98.45 \pm 0.60^{\circ} \mathrm{F}$ respectively. The antipyretic effect was compared with that of aspirin, which was found to be more potent and brought down the temperature to $96.9 \pm 0.38^{\circ} \mathrm{F}(\mathrm{P}<0.001)$. This study suggests that DL of $C$. procera has actions similar to aspirin. The antipyretic activity of $C$. procera in experimental rats was also investigated [109]. The antipyretic effect retained the test and was comparable to that of acetylsalicylic acid used as the standard drug.

\section{Anti-Oxidant Activity}

Scientific evidence suggests that under oxidative stress conditions, oxygen radicals such as superoxide anion $\left(\mathrm{O}^{-}\right)$, hydroxyl radical $(-\mathrm{OH})$ and peroxyl radicals $\left(\mathrm{H}_{2} \mathrm{O}_{2}\right)$ are produced in biological systems. These oxygen radicals are called Reactive Oxygen Species (ROS) and they can lead to oxidative damage to cellular components such as proteins, lipids and DNA. These oxygen radicals play important roles in degenerative processes such as ageing [110], cardiovascular diseases, cancer, Alzheimer's disease and other neurodegenerative diseases, [111-113]. Antioxidants are reported to boost the function of immune cells against homeostatic disturbance and their free radical scavenging activity has been substantially investigated [114]. Similarly, the antioxidant potential of the methanolic extract was determined on the basis of their scavenging activity of the stable 1, 1-diphenyl-2-picryl hydrazyl (DPPH) free radical. $\mathrm{IC}_{50}$ of the methanol extract of $C$. procera was $110.25 \mu \mathrm{g} / \mathrm{ml}$ indicating the strong antioxidant activity of the plant. However, the aqueous extract showed mild antioxidant activity [102].

The antioxidant potential of the root, leaf extracts and latex of field grown as well as tissue cultured $C$. procera plants were analyzed [115]. Free radical scavenging activity was determined by DPPH. The highest antioxidant capacity was exhibited by extracts of lyophilized latex $\left(\mathrm{IC}_{50}=0.060 \mathrm{mg} / \mathrm{ml}\right)$ and the lowest $\left(\mathrm{IC}_{50}=\right.$ $0.27 \mathrm{mg} / \mathrm{ml}$ ) was in root extracts of field grown plants. The obtained results thus provided a support for the use of $C$. procera in traditional medicine and suggest its further advance investigation. Antioxidant effect of latex of C. procera against alloxan-induced diabetic rats was evaluated [116]. DL produced an increase in the hepatic levels of the endogenous antioxidants, namely superoxide dismutase (SOD), catalase and glutathione, while it brought down the levels of thiobarbituric acid-reactive substances (TBARS) in alloxan-induced diabetic rats. The efficacy of DL as an antioxidant agent was comparable to the standard drug, glibenclamide.

\section{Wound Healing Activity}

Based on its traditional use, C. procera was selected for evaluation of its wound healing potential in guinea pigs [117], for this purpose four full thickness excision wounds of $8.0 \mathrm{~mm}$ diameter were inflicted on the back of guinea pigs. Topical application of $20 \mu \mathrm{l}$ of $1.0 \%$ sterile solution of the latex of the plant, twice daily was followed for 7 days. The latex significantly augmented the healing process by markedly increasing collagen, DNA and protein synthesis and epithelisation leading to reduction in wound area. Thus the result provided a scientific rationale for the traditional use of this plant in the management of wound healing.

\section{Protective Activity}

Hydro-ethanolic extract (70\%) of C. procera flowers was prepared and tested for its hepatoprotective effect against paracetamol-induced hepatitis in rats [118]. Alteration in the levels of biochemical markers of hepatic damage like SGPT, SGOT, ALP, bilirubin, cholesterol, HDL and tissue GSH were tested in both treated and untreated groups. Paracetamol $(2 \mathrm{~g} / \mathrm{kg})$ has enhanced the SGPT, SGOT, ALP, bilirubin and cholesterol levels and reduced the serum levels of HDL and tissue level of GSH. Treatment with hydro-ethanolic extract of C. procera flowers $(200 \mathrm{mg} / \mathrm{kg}$ and $400 \mathrm{mg} / \mathrm{kg}$ ) has brought back the altered levels of biochemical markers to the near normal levels in the dose dependent manner.

The alcoholic extract of the latex obtained from C. procera was evaluated for protection against isoproterenol $(20 \mathrm{mg} / 100 \mathrm{~g}$ body wt., s.c.) induced myocardial infarction in albino rats [119]. The heart damage induced by isoproterenol was indicated by elevated levels of the marker enzymes such as Creatine Kinaseisoenzyme (CK-MB), Lactate dehydrogenase (LDH), Serum Glutamate Oxaloacetic Transaminase (SGOT) and Serum Glutamate Pyruvate Transaminase (SGPT) in serum with increased lipid peroxide and reduced glutathione content in heart homogenates. Microscopical examination (histopathology) was also performed on 
the myocardial tissue. Pretreatment with an ethanolic latex extract of $C$. procera at a dose of $300 \mathrm{mg} / \mathrm{kg}$ body wt., administered orally thrice a day for 30 days, reduced significantly $(p<0.01)$ the elevated marker enzyme levels in serum and heart homogenates in isoproterenol-induced myocardial infarction. Histopathological observation revealed a marked protection by the extract in myocardial necrotic damage.

The protective effects of latex of $C$. procera in Freund's Complete Adjuvant (FCA) induced monoarticular arthritis in rats were observed [120]. Daily oral administration of dried latex (DL) and its methanol extract (MeDL) produced a significant reduction in joint inflammation (about 50\% and 80\% inhibition) and associated hyperalgesia. The anti-hyperalgesia effect of MeDL was comparable to that of rofecoxib. Both DL and MeDL produced a marked improvement in the motility and stair climbing ability of the rats. The histological analysis of the arthritic joint also revealed significant reduction in oedema and cellular infiltration by MeDL that was comparable to that of rofecoxib. Thus, the result suggests that the latex of $C$. procera has the potential to be used as an anti-arthritic agent and hence concluded as an efficient protective agent.

\section{Analgesic Activity}

An analgesic (also known as a painkiller) is any member of the diverse group of drugs used to relieve pain (achieve analgesia). The word analgesic derives from Greek an- ("without") and algos ("pain"). Analgesic drugs act in various ways on the peripheral and central nervous systems; they include paracetamol (acetaminophen), the non-steroidal anti-inflammatory drugs (NSAIDs) such as the salicylates, narcotic drugs such as morphine, synthetic drugs with narcotic properties such as tramadol, and various others.

Henceforth, the analgesic activity of dry latex (DL) of C. procera was evaluated [59]. A single oral dose of DL ranged from 165 to $830 \mathrm{mg} / \mathrm{kg}$ produced a significant dose dependent analgesic effect against acetic acid induced writhings. The effect of DL at a dose of $415 \mathrm{mg} / \mathrm{kg}$ was more pronounced as compared to a $100 \mathrm{mg} / \mathrm{kg}$ oral dose of aspirin. On the other hand DL $(830 \mathrm{mg} / \mathrm{kg}$ ) produced marginal analgesia in a tail-flick model which was comparable to aspirin. The analgesic effect of DL was delayed by $1 \mathrm{~h}$ by naloxone at a dose of $0.5 \mathrm{mg} / \mathrm{kg}$, i.p., which completely blocked the analgesic effect of morphine $(10 \mathrm{mg} / \mathrm{kg}$, i.p.). However, the effect of aspirin was not blocked by naloxone. The $830 \mathrm{mg} / \mathrm{kg}$ oral dose of DL did not produce toxic effects in mice and the $\mathrm{LD}_{50}$ was found to be $3 \mathrm{~g} / \mathrm{kg}$. A significant analgesic property by the hot plate method was showed [25] which were described previously against mice [121]. It is clearly concluded that $C$. procera shows tremendous analgesic activity which is a boom for medicinal world.

\section{Acaricidal Activity}

Acaricides (or miticides) are pesticides that kill ticks and mites. Antibiotic miticides, carbamate miticides, formamidine miticides, mite growth regulators, organochlorine, permethrin and organophosphate miticides are all in this category. Similarly, the cardiac glycoside (cardenolide) extract from C. procera was tested for the effect against larvae and adult stages of the camel tick, Hyalomma dromedarii Koch (Acari: Ixodidae) [122]. The contact $\mathrm{LC}_{50}$ value of the material against adults was $9.63 \mu \mathrm{gcm}^{-2}$ whereas the dipping $\mathrm{LC}_{50}$ value of the material was $1096 \mathrm{mg} / \mathrm{litre}^{-1}$. Contact and dipping $\mathrm{LC}_{50}$ values of the extract against larvae were $6.16 \mathrm{~cm}^{-2}$ and $587.7 \mathrm{mg}$ litre $\mathrm{e}^{-1}$. Results of the cardiac glycoside material were compared with those of several commercial acaricides and the risks and benefits associated with the use of cardiac glycoside were considered.

\section{Antinociceptive Activity}

Nociception is defined as "the neural processes of encoding and processing noxious stimuli". It is the afferent activity produced in the peripheral and central nervous system by stimuli that have the potential to damage tissue. This activity is initiated by nociceptors (also called pain receptors), that can detect mechanical, thermal or chemical changes, above a set threshold. Once stimulated, a nociceptor transmits a signal along the spinal cord, to the brain. Nociception triggers a variety of autonomic responses and may also result in the experience of pain in sentient beings.

The antinociceptive effect of proteins from the $C$. procera latex was evaluated using three different experimental models of nociception in mice [123]. The latex protein fraction administered intraperitoneally in male mice at the doses of $12.5,25$ and $50 \mathrm{mg} / \mathrm{kg}$ showed the antinociceptive effect in a dose dependent manner compared to the respective controls in all assays. Inhibitions of the acetic acid-induced abdominal constrictions were observed at the doses of $12.5(67.9 \%), 25(85 \%)$ and $50(99.5 \%) \mathrm{mg} / \mathrm{kg}$ compared to controls. Latex protein at the dose of $25(39.8 \% ; 42 \%)$ and $50 \mathrm{mg} / \mathrm{kg}(66.6 \% ; 99.3 \%)$ reduced the nociception produced by formalin in the 1st and 2nd phases, respectively, and this effect was not reversed by pretreatment with naloxone $(1 \mathrm{mg} / \mathrm{kg})$. In the hot plate test, an increase of the reaction time was observed only at $60 \mathrm{~min}$ after the treatment with latex at the dose of $25(79.5 \%)$ and $50(76.9 \%) \mathrm{mg} / \mathrm{kg}$, compared to control and naloxone was ineffective to reverse the effect. It was concluded that the protein fraction derived from the whole latex of the giant milk weed possesses antinociceptive activity, which is independent of the opioid system. 


\section{Antiulcer Activity}

The antiulcer activity of $C$. procera using different in vivo ulcer models were reported [124]. The results of the study revealed that it significantly inhibited aspirin, reserpine, absolute alcohol and serotonininduced gastric ulcerations in rats and also protecting the gastric mucosa from aspirin-induced ulceration in pyloric-ligated rats and significant protection was observed in histamine-induced duodenal ulcers in guinea-pigs.

\section{Anti-Fertility Activity}

The effect of ethanolic extract of the roots of C. procera in albino rats was studied [125] to explore its anti-fertility and hormonal activities. A strong anti-implantation (inhibition 100\%) and uterotropic activity was observed at the dose level of $250 \mathrm{mg} / \mathrm{kg}\left(1 / 4\right.$ of $\left.\mathrm{LD}_{50}\right)$.

\section{Anti-Coccidial Activity}

Coccidiosis is the disease caused by coccidian infection. Coccidiosis is a parasitic disease of the intestinal tract of animals, caused by coccidian protozoa. The disease spreads from one animal to another by contact with infected feces or ingestion of infected tissue. Diarrhea, which may become bloody in severe cases, is the primary symptom. Most animals infected with coccidia are asymptomatic; however, young or immunocompromised animals may suffer severe symptoms, including death.

The comparative anti-coccidial activity of $C$. procera latex and sulfadimidine was examined in experimental Eimeria ovinoidalis infection in Najdi lambs which had been infected with single oral doses of 150,000 infective oocysts [126]. The symptoms revealed positive for coccidiosis in Najdi lambs. They were treated with single oral doses of $0.02 \mathrm{ml} / \mathrm{kg}$ body weight of $C$. procera latex or $2 \mathrm{~g} / \mathrm{kg}$ body weight of sulfadimidine, oocysts production was considerably suppressed 4 days post-treatment and feces were completely free from oocysts between 7 and 17 days after treatment with both $C$. procera latex and sulfadimidine. These findings were accompanied by a return of normal appetite and activity, regular pelleted feces and markedly reduced number of schizonts in intestinal cells. Although bouts of diarrhea were severe post-infection, the concentration of serum sodium returned to normal but that of potassium remained high after therapy with $C$. procera latex and sulfadimidine. Repetition of dosing lambs with $C$. procera latex and sulfadimidine was suggested.

\section{Schizontocidal Activity}

Schizonts are protozoan cells that divide by schizogony and $C$. procera acts an agent (schizontocide) to kill these schizonts. Good record keeping of subjective and objectively recorded cures by practitioners of traditional medicinal system will help in the establishment of the use of $C$. procera as an antimalarial plant. Researchers attempted to see the effect of crude fractions of its flower, bud and root against a chloroquine sensitive strain, MRC 20 and a chloroquine resistant strain, MRC 76 of Plasmodium falciparum using the Desjardins method and the effectiveness of its fractions compare better with the CQ sensitive strain than the CQ resistant strain in vitro [62]. Whereas, again the scientists evaluated the ethanol extracts of the plant leaves, stems, roots, flowers and buds and screened in vitro for schizontocidal activity against chloroquine (CQ)sensitive and CQ-resistant Plasmodium falciparum strains [62].

\section{The Plant}

Calotropis procera (Giant milkweed) is known as sodom apple, calotrope, French cotton, small crown flower (English), algodón de seda, bomba (Spanish), cotton-france, arbre de soie, and bois canon (French) [54]. This plant is a soft-wooded, evergreen, perennial shrub. It has one or a few stems, few branches, and relatively few leaves, mostly concentrated near the growing tip. The bark is corky, furrowed, and light gray. A copious white sap flows whenever stems or leaves are cut. It has a very deep, stout taproot with few or no near-surface lateral roots. Its roots were found to have few branches and reach depths of 1.7 to $3.0 \mathrm{~m}$ in Indian sandy desert soils [127]. The opposite leaves are oblongobovate to nearly orbicular, short-pointed to blunt at the apex and have very short petioles below a nearly clasping, heart-shaped base. The leaf blades are light to dark green with nearly white veins. They are 7 to $18 \mathrm{~cm}$ long and 5 to $13 \mathrm{~cm}$ broad, slightly leathery, and have a fine coat of soft hairs that rub off. The flower clusters are umbelliform cymes that grow at or near the ends of twigs. The flowers are shallowly campanulate with five sepals that are 4 to $5 \mathrm{~mm}$ long, fleshy and variable in color from white to pink, often spotted or tinged with purple. The fruits are inflated, obliquely ovoid follicles that split and invert when mature to release flat, brown seeds with a tuft of white hairs at one end.

The latex of the giant milk weed is well known for its toxic as well as for various medicinal properties. The latex can cause blisters and rash in sensitive persons. The plant is occasionally grown as an ornamental in dry or coastal areas because it is handsome, of a convenient size, and is easy to propagate and manage. 
C. procera is classified into 10 groups i.e. Kingdom- Plantae, Subkingdom- Tracheobionta, SuperdivisionSpermatophyta, Division- Magnoliophyta, Class- Magnoliopsida, Subclass- Asteridae, Order- Gentianales, Family- Asclepiadaceae, Genus- Calotropis and Species- procera. It is native to West Africa as far South as Angola, North and East Africa, Madagascar, the Arabian Peninsula, Southern Asia, and Indochina to Malaysia [128]. The species is now naturalized in Australia, many Pacific islands, Mexico, Central and South America.

\subsection{Endophytic Fungi from $C$. procera}

Endophytic fungi are those which live inside the tissues of living plants and are under-explored group of microorganisms. These are diverse group of organisms that make symbiotic associations with higher life forms and may produce beneficial substances for host $[129,130]$. Recently they have received considerable attention after they were found to protect their host against insect pests, pathogens and even domestic herbivores $[129,130,131]$. Endophytic fungi generally live peacefully with their host, while these fungi under different conditions may act as facultative pathogen. One of the important roles of endophytic fungi is to initiate the biological degradation of dead or dying host-plant, which is necessary for nutrient recycling [132]. Calotropis procera is a widely used medicinal plant in Indian sub-continent, was investigated for endophytic mycoflora as a possible source of bioactive secondary metabolites [133]. A total of 8 fungal species viz., Aspergillus flavus, A. niger, Aspergillus sp., Penicillium sublateritium, Phoma chrysanthemicola, P. hedericola, Phoma sp., and Candida albicans were isolated. Among the endophytic flora, Phoma was the most prominent genus. The profuse pycnidia were found on the dead plants of C. procera which is the characteristic of the fungus Phoma, the most common endophyte of this plant. The Phoma species are reported to produce cellulytic enzymes, necessary to degrade plant material [134]. Interestingly, no endophyte was isolated from 118 leaves samples and overall colonization frequency from surface sterilized stem was $8.86 \%$. In their study, Deuteromycota fungi were largely prevalent. Majority of endophytic fungi belongs to Ascomycota and Deuteromycota [135]. A study of endophyte biodiversity of the two dry tropical forest of the Nilgiri Biosphere Reserve in India was conducted [136]. A monthly survey from 1989-1991 was conducted to examine the effect of seasons on the inhabited surface fungi on leaves of medicinal plant, C. procera [137]. A total number of 46 species of 21 genera of fungi from the plant were isolated. A high percent of fungi was obtained during May while the lowest percentage was recorded in September. Alternaria (7 species) was the most predominant genus on leaves of $C$. procera. Alternaria alternata, Aspergillus flavus, A. niger and Penicilium chrysogenum were isolated during all seasons on the leaves of the plant.

\subsection{C. procera as a potent biosorbent}

The leaf biomass of the plant is potentially a good adsorbent for the removal of crystal violet (a cationic) from aqueous solution [17]. The cation binding capacity of the adsorbent biomass can be enchanced by its treatment with alkalies like sodium hydroxide. Most plant tissue has cellulose, hemicellulose and ligin as their major constituents. These constituents contain methyl esters, which do not bind metal ions (cations) significantly. The methyl esters can be converted to carboxylate ligands by treatment of a biomass with alkalies like sodium hydroxide. The performance of the leaf biomass of the plant as biosorbent for the textiles dyes can be evaluated by comparing its uptake capacity with other biosorbents.

\subsection{C. procera as a source of Plant hydrocarbons}

C. procera was evaluated as a potential source of hydrocarbons [18]. Hexane Soxhlet extraction of oven-dried whole plants, stems, leaves and pods ( $\geq 6 \mathrm{mo}$ of age) yielded $4.35,3.83,5.13$, and $9.37 \%(\mathrm{w} / \mathrm{w})$ hexane extract (HE), respectively. The HE from whole plants has a density of $0.9299 \mathrm{~g} / \mathrm{cm}^{3}, 0.71 \%$ total ash, $9973.4 \mathrm{cal} / \mathrm{g}$ and $78.03,11.22$ and $10.71 \%$ carbon, hydrogen and oxygen, respectively. Similar values were obtained from stems, leaves and pods when analyzed separately. Methanol Soxhlet extractions of residues previously extracted with hexane yielded $16.14,18.50,12.15$ and $20.68 \%(\mathrm{w} / \mathrm{w})$ methanol extract (ME) from whole plants, stems, leaves and pods, respectively. The ME from whole plant residues had a density of 1.2267 glcm $3,12.05 \%$ total ash, 4,647.4 callg, and 40.88, 6.86, and 30.05\% carbon, hydrogen and oxygen, respectively. Similar values were obtained from stems, leaves and pods when analyzed separately.

\section{Conclusion}

C. procera (giant milk weed) has been used as traditional folk medicine by many cultures, and it has been the subject of extensive phytochemical and bioactive investigations. It had shown significant pharmacological importance representing as a strong contender in the medical arena. It is a useful botanical monitor of pollution because of the variation found in the concentrations of $\mathrm{Br}, \mathrm{Mn}, \mathrm{Se}, \mathrm{Cr}$ and $\mathrm{Zn}$ between urban and suburban samples. The plant has proved to be a good indicator for the determination of above elements when it is exposed to them from any source. Historically, the plant is being used in rural community 
for pest control and as a remedial agent against various diseases. It is therefore, interesting to study the biological activity of this plant in depth to evaluate their efficacy after characterizing the bioactive principle. We believe that intensive and systemic investigation of this plant will give new insight for further pharmacological and phytochemical research.

\title{
Acknowledgement
}

We wish to express our gratitude to Council of Scientific and Industrial Research (CSIR), New Delhi for the award of Emeritus Scientist to Prof. P.S. Bisen.

\author{
DL- Dried latex \\ CAM- Complementary and alternative medicine \\ LP- Protein fraction of the latex
}

Abbreviations

\section{References}

[1] El- MS, Towards rational use of herbal products: The need for adequate legislation. Saudi Pharmaceutical Journal, 2, 1994, 153155.

[2] Ghani A, Medicinal Plants of Bangladesh with chemical constituents and uses Asiatic Society of Bangladesh, Nimtali, Dhaka 2003.

[3] Irvine FR, Woody plants of Ghana. Oxford University Press, London, 1961.

[4] Waleed JA. Response of Calotropis Procera for Urban, Suburban and Sewage Pollution. Umm Al-Qura Univ J Sci Med Eng 2006; 18(1):31-40.

[5] Chungsamarnyart N, Ratanakreetakul C, Jansawan W. Acaricidal activity of the combination of plant crude extracts to tropical cattle ticks. Kasetsart Journal, Natural Sciences 1994; 28(4):649-660.

[6] Nandal SN, Bhatti DS. Preliminary Screening of Some Weeds Shrubs for Their Nematocidal Activity against MeloidogyneJavanica. Indian Journal of Nematology 1983; 13:123-127.

[7] Rakesh P, Alok K, Neetu K. Nematicidal activity in flowers of some medicinal and aromatic plants. Indian J Nematol 2001; 31:9698.

[8] Malik NN, Chughtai MID. Antimicrobial activity of Calotropis procera. A preliminary study. Pakistan J Sci 1979; 31:127-129.

[9] Hussein HI, Kamel A, Abou-Zeid M, El-Sebae A-KH, Saleh MA. Uscharin, the most potent molluscicidal compound tested against land snails. J Chem Ecol 1994; 20:135-140.

[10] Girdhar G, Deval K, Mittal PK, Vasudevan P. Mosquito Control by Calotropis-Procera Latex. Pesticides 1984;18:26-29.

[11] Jacob S, Sheila M.K. A note on the protection of stored rice from the lesser grain borer, Rhozopthera dominica Fabr. By indigenous plant products. Indian J Entomol 1993;55 (3):337-339.

[12] Khan SM, Siddiqui MN. Potential of some indigenous plants as pesticides against the larvae of cabbage butterfly Pieris brassicae L. Sarhad Journal of Agriculture 1994; 10:291-297.

[13] Moursey LE. Insecticidal activity of Calotropis procera extracts of the flesh fly, Sarcophaga haemorrhoidalis fallen. J Egypt Soc Parasitol 1997;27:505-514.

[14] Smit HF, Woerdenbag HJ, Singh RH, Meulenbeld GJ, Labadie RP, Zwaving JH. Ayurvedic herbal drugs with possible cytostatic activity. J Ethnopharmacol 1995;47:75-84.

[15] Choedon T, Mathan G, Arya S, Kumar VL, Kumar V. Anticancer and cytotoxic properties of the latex of Calotropis procera in a transgenic mouse model of hepatocellular carcinoma World J Gastroentero 2006;12:2517-2522.

[16] Mascolo N, Sharma R, Jain SC, Capasso F. Ethnopharmacology of Calotropis procera flowers. J Ethnopharmacol 1988; 22:211221.

[17] Ali H, Muhammad SH, Biosorption of crystal violet from water on leaf biomass of Calotropis procera. J Environ Sci Technol 2008; 1(3):143-150.

[18] Erdman MD, Erdman BA, Calotropis procera as a source of plant hydrocarbons. Economic Botany 1981;35(4):467-472.

[19] Sehgal R, Kumar VL. Calotropis procera Latex-Induced Inflammatory Hyperalgesia - Effect of Antiinflammatory Drugs. Mediators Inflamm 2005;4:216-220.

[20] Padhy BM, Kumar VL. Inhibition of Calotropis procera latex-induced inflammatory hyperalgesia by oxytocin and melatonin. Mediators Inflamm 2005;2005(6):360-365.

[21] Shivkar YM, Kumar VL. Effect of anti-inflammatory drugs on pleurisy induced by latex of Calotropis procera in rats. Pharmacol Res 2004; 50:335-340.

[22] Singh H, Kumar S, Dewan S, Kumar V.L. Inflammation induced by latex of Calotropis procera - a new model to evaluate antiinflammatory drugs. J Pharmacol Toxicol Methods 2000; 43(3):219-224.

[23] MueenAhmed KK, Rana AC, Dixit VK. Calotropis Species (Asclepiadiaceae) - A Comprehensive Review. Phcog Mag 2005; 1(2):48-52.

[24] Chopra RN, Nayar SI, Chopra IC, Glossary of Medicinal Plants. C.S.I.R. New Delhi 1956.

[25] Mossa JS, Tariq M, Mohin A, Ageel AM, Al-Yahya MA. Al-said MS et al. Pharmacological studies on aerial parts of Calotropis procera. Am J Chin Med 1991; 19:223-31.

[26] Ansari SH, Ali M. New oleanene triterpenes from root bark of Calotropis procera. J Med Aromat Plant Sci 1999; $21: 978-981$.

[27] Ansari SH Ali M. Norditerpenic ester and pentacyclic triterpenoids from root bark of Calotropis procera (Ait) R. Br. Pharmazie 2001;56:175-177.

[28] Gupta A. Singh R. Purwar C. Chauhan D. Singh J. Two pentacyclic triterpenes from the stem of Calotropis procera. Indian J Chem 2003; 42:2030.

[29] Khan AQ, Ahmed Z, Kazmi SNH, Malik A. A New Pentacyclic Triterpene from Calotropis procera. J Nat Prod 1988; $51: 925-928$.

[30] Seiber JN, Nelson CJ, Lee SM. Cardenolides in the Latex and Leaves of 7 Asclepias-Spp and Calotropis-Procera. Phytochemistry $1982 ; 21: 2343-2348$.

[31] Khan AQ, Malik A. A steroid from Calotropis procera. Phytochemistry 1989; 28(10):2859-2861.

[32] Khanzada SK, Shaikh W, Kazi TG, Sofia S, Kabir A, Usmanghani K, Kandhro AA. Analysis of fatty acid, elemental and total protein of Calotropis procera medicinal plant from Sindh, Pakistan. Pak J Bot 2008; 40(5):1913-1921. 
[33] Hesse G, Reichender F. African arrow poison calotropin I. Justus Lieb Ann Chem 1936; 526:252-276.

[34] Hesse G, Reichender F, Eysenbach H. African arrow poisons II. Heart poisons in Ccilolropis latex. Justus Lieb Ann Chem 1938; 537:67.

[35] Hesse G, Heuser LJ, Hutz E, Reichender F. African arrow poisons V. Relationships between the most important poisons of Calotropis procera. Justus Lieb Ann Chem 1950; 566:130-139.

[36] Rajagopalan S, Tamm Ch, Reichstein T. Die Glykoside der Samen von Calotropis procera R .Br. Helv Chim Acta, 1955;38:18091824 .

[37] Hesse G, Lettenbauer G. A 2nd sulfur-containing compound from the milky-juice of Calotropis procera. Angew Chem 1957;69, 392.

[38] Hassal K, Reyle K. Cardenolides. Part III. The constitution of calotropagenin. J Chem Soc 1959;85-89. (DOI: 10.1039/JR9590000085).

[39] Hesse G, Ludwing G. African arrow poisons XIV. Voruscharine, a second sulfur-containing heart poison from Calotropis procera L. Justus Lieb Ann Chem 1960;632:158-171.

[40] Ibrahim RK Phenolic constituents of the oil flax (Linum usitatissimum). Phytochemistry 1970;9(8):1855-1858.

[41] Anjaneyulu V, Ramachandra Row L. The triterpenes of Calotropis gigatea Linn. Curr Sci 1968;6:156-157.

[42] Chandler RF, Coombe RG, Watson TR. The digitanols of the root bark of Calotropis procera R.Br. Aus J Chem 1968; 21(6):16251631.

[43] Brueschweiler F, Stockel K, Reichstein T. Calotropis - Glycoside, vermutliche Teilstruktur. Helv Chim Acta, 1969;52:2276-2303.

[44] Bhaskar VH, Ajay SS. Evaluation of Antihperglycemic Activity of Extracts of Calotropis procera (Ait.) R.Br on Streptozotocin Induced Diabetic Rats. Global J Pharmacol, 2009; 3(2): 95-98.

[45] Saber AH, Mahran JH, Rizkallah. Sterols and pentacyclic triterpenes of Calotropis procera. Bull Fac Pharm Cario Uni 1968;7 (1):91-94.

[46] Pant R Chaturvedi K. Chemical analysis of Calotropis procera latex. Curr Sci 1989;58(13):740-724.

[47] Khan AQ, Malik A Phytocehemical investigation Calotropis procera. Fitoterapia 1990;61(1):89.

[48] Dubey VK, Jagannadham MV. Procerain, a stable cysteine protease from the latex of Calotropis procera. Phytochemistry 2003;62(7):1057-1071.

[49] Hassan SW, Bilbis FL, Ladan MJ, Umar RA, Dangoggo SM, Saidu Y, et al. Evaluation of Antifungal Activity and Phytochemical Analysis of Leaves, Roots and Stem Barks Extracts of Calotropis procera (Asclepiadaceae). Pak J Biol Sci 2006;9(14):2624-2629.

[50] Gallegos-Olea RS, Borges MOR, Borges ACR, Freire SMF, Silveira LMS, Vilegas W et al. Flavonoides de Calotropis procera R. Br. (Asclepiadaceae). Rev Bras Pl Med, Botucatu 2008;10(1):29-33.

[51] Alam P, Ali M. Phytochemical investigation of Calotropis procera Ait roots. Indian J Chem 2009;48:443-446.

[52] Edith A, Mofolusho F, Omonike O, Larry O, Dora A. In vivo antimalarial and cytotoxic properties of Annona senegalenisis extract. African J Tradit Complement Altern Med 2005;3(1):138-139.

[53] Sing AK, Raghubanshi AS, Sing JS. Medical ethnobotany of the tribals of Sonaghati of Sonbhadra district, Uttar Pradesh, India. $J$ Ethnopharmacol 2002;81(1):31-41.

[54] Parrotta JA, Healing plants of Peninsular India. CAB International, Wallingford, UK and New York 2001.

[55] Anver S, Alam MM. Effect of latex seed dressing on interacting root-knot and reniform nematodes. Afro-Asian Journal of Nematology 1992;2:17-20.

[56] Charu J, Trivedi PC. Nematicidal activity of certain plants against root-knot nematode, Meloidogyne incognita, infecting chickpea, Cicer arietinum. Annals of Plant Protection Sciences 1997;5(2):171-174.

[57] Shivkar YM, Kumar VL. Antihelmintic Activity of Latex of Calotropis procera. Pharm Biol 2003; 41(4):263-265.

[58] Kumar VL, Shivkar YM. In vivo and in vitro effect of latex of Calotropis procera on gastrointestinal smooth muscles. $J$ Ethnopharmacol 2004; 93:377-379.

[59] Dewan S, Kumar S, Kumar VL. Antipyretic effect of latex of Calotropis procera. Indian J Pharmacol 2000;32:252.

[60] Kumar VL, Basu N. Anti-inflammatory activity of the latex of Calotropis procera. J Ethnopharmacol 1994; 44(2):123-125.

[61] Kumar S, Dewan S, Sangraula H, Kumar VL. Anti-diarrhoeal activity of the latex of Calotropis procera. J Ethnopharmacol 2001;76(1):115-118.

[62] Sharma P, Sharma JD. In-vitro schizonticidal screening of Calotropis procera. Fitoterapia, 2000;71(1):77-79.

[63] Schimmer O, Kruger A, Paulin H, Haefele F. An Evaluation of 55 Commercially pants extract in the Ames Mutagenicity Test. Pharmazie 1994; 49:448-451.

[64] Prakash D, Alam MM, Ashraf S, Khan AM. Studies on Rhizosphere Myco Flora of Eggplant in Relation to Soil Amendments. Acta Bot Indica 1976;4:68-70.

[65] Ramos MV, Bandeira GDP, De Freitas CDT, Pinto Nogueira NA, Nunes Alencar NM, Simao de Sousa PA et al. Latex constituents from Calotropis procera (R. Br.) display toxicity upon egg hatching and larvae of Aedes aegypti (Linn.). Mem Inst Oswaldo Cruz. 2006;101:503-510.

[66] Jain SC, Sharma R, Jain R, Sharma RA. Antimicrobial activity of Calotropis procera. Fitoterapia 1996; 67:275-276.

[67] Fleurentin J, Pelt JM. Repertory of drugs and Medicinal plants of Yemen. J Ethnopharmacol 1982;5:85-108.

[68] Kumar VL Arya S. Medicinal uses and pharmacological properties of Calotropis procera. In: J.N. Govil, Editor, Recent Progress in Medicinal Plants 11, Studium Press, Houston, Texas, USA 2006,333-388.

[69] Samvatsar S, Diwanji VB. Plant sources for the treatment of jaundice in the tribals of Western Madhya Pradesh of India. $J$ Ethnopharmacol 2000;73:313-6.

[70] Parkin DM, Bray F, Ferlay J, Pisani P, Global cancer statistics, 2002. CA Cancer J Clin 2005; 55:74-108.

[71] Peto J. Cancer epidemiology in the last century and the next decade. Nature 2001; 411:390-395.

[72] Molassiotis A, Fernadez-Ortega P, Pud D, Ozden G, Scott JA, Panteli V. et al. Use of complementary and alternative medicine in cancer patients: a European survey. Ann Oncol 2005;16:655-663.

[73] Yates JS, Mustian KM, Morrow GR, Gillies LJ, Padmanaban D, Atkins JN. et al, Prevalence of complementary and alternative medicine use in cancer patients during treatment. Support Care Cancer 2005; 13:806-811.

[74] Oliveira JS, Bezerra DP, De Freitas CD, Filho JD, Moraes MO, Pessoa C, Costa-Lotufo L, Ramos MV. In vitro cytotoxicity against different human cancer cell lines of laticifer proteins of Calotropis procera (Ait.) R. Br. Toxicol in Vitro 2007;21:1563-1573.

[75] Sehgal R, Roy S, Kumar VL. Evaluation of cytotoxic potential of latex of Calotropis procera and Podophyllotoxin in Allum cepa root model. Biocell 2006;30(1):9-13.

[76] Sharma CBSR. Plant meristems as monitors of genetic toxicity of environmental chemicals. Curr Sci 1983;52:1000-1002.

[77] Mathur R, Gupta SK, Mathur SR, Velpandian T. Anti-tumor studies with extracts of Calotropis procera (Ait.) R.Br. root employing Hep2 cells and their possible mechanism of action. Indian J Exp Biol 2009;47(5):343-348. 
[78] Arya S, Kumar VL, Antiinflammatory Efficacy of Extracts of Latex of Calotropis procera Against Different Mediators of Inflammation. Mediators Inflamm 2005;4:228-232.

[79] Majumder PK, Kumar VL. Anti-inflammatory Activity of Fractions of Latex of Calotropis procera in Carrageenan Induced Rat Paw Oedema. Phytother Res 1998;11(2):166-167.

[80] Sangraula H, Dewan S, Kumar VL. Evaluation of anti-inflammatory activity of latex of Calotropis procera in different models of inflammation. Inflammopharmacology 2002;9(3):257-264.

[81] Kumar VL, Roy S. Calotropis procera Latex Extract Affords Protection against Inflammation and Oxidative Stress in Freund's Complete Adjuvant-Induced Monoarthritis in Rats. Mediators Inflamm 2007 Doi: 10, 1155/ 2007/ 47523.; 1-7.

[82] Maillard M, Marston A, Hostettmann K. Search for molluscicidal and larvicidal agents from plants. In Balandrin M. Human Medicinal Agents from Plants, American Chemical Society, Washington D.C. 1993.

[83] Carvalho AFU, Melo VMM, Craveiro AA, Machado MIL, Bantim MB, Rabelo EF. Larvicidal activity of the essential oil from Lippia sidoides Cham. against Aedes aegypti Linn. Mem Inst Oswaldo Cruz 2003; 98:569-571.

[84] Markouk M, Bekkouche K, Larhsini M, Bousaid M, Lazrek HB, Jana M. Evaluation of some Moroccan medicinal plant extracts for larvicidal activity. J. Ethnopharmacol 2000; 73(1-2):293-297.

[85] Al-Doghairi MA, El Hag E. Effect of several biopesticides on alfalfa weevil larvae, Hypera brunneipennis (Boheman). Pak J Biol Sci 2003; 6(8):777-781.

[86] Singhi M, Joshi V, Sharma RC, Sharma K. Ovipositioning Behaviour of Aedes aegypti in Different Concentrations of Latex of Calotropis procera: Studies on Refractory Behaviour and its Sustenance across Gonotrophic Cycles. Dengue Bulletin 2004;28:184188.

[87] Abbassi K, Kadiri ZA, Ghaout S. Biological activity of Calotropis procera (Ait. R. Br) leaves on the desert locust (Schistocerca gregaria, Forsk. 1775). Zool. Baetica 2004;15:153-166.

[88] Ahmed UAM, Zuhua S, Bashier NHH, Muafi K, Zhongping H, Yuling G. Evaluation of Insecticidal Potentialities of Aqueous Extracts from Calotropis procera Ait. Against Henosepilachna elaterii Rossi. J Appl Sci 2006; 6(11):2466-2470.

[89] Badshah H, Farmanullah, Salihah Z, Saljoqi AUR, Shakur M. Toxic Effects of Ak (Calotropis procera) Plant Extracts Against Termites (Heterotermes indicola and Coptotermes heimi) Isoptera: Rhinotermitidae. J Appl Sci 2004;7(9):1603-1606.

[90] Rahuman AA, Bagavan A, Kamaraj C, Saravanan E, Zahir AA, Elango G. Efficacy of larvicidal botanical extracts against Culex quinquefasciatus Say (Diptera: Culicidae). Parasitol Res 2009;104(6):1365-1372.

[91] Ahmed S, Fiaz S, Riaz MA, Hussain A. Comparative Efficacy of Datura alba nees, Calotropis Procera and Imidacloprid on termites in sugarcane at Faisalabad. Pak. Entomol. 2005;27(2):11-14.

[92] Evans, W.C. 1996. Trease and Evans' Pharmacognosy. W.B. Saunders Company Ltd, London 1997.

[93] Karaman I, Sahin F, Gulluce M, Ogutcu H, Sengul M, Adiguzel A. Antimicrobial activity of aqueous and methanol extracts of Juniperus oxycedrus. J Ethnopharmacol 2003;85(2-3):231-235.

[94] Lis-Balchin M, Deans SG. Bioactivity of selected plant essential oils against Listeria monocytogenes. J Appl Bacteriol 1997;82(6):759-762.

[95] Mann A, Abalaka ME, Garba SA. The antimicrobial activity of the leaf extracts of Calotropis procera. Biomed Lett 1997;55(219):205-210.

[96] Sehgal R, Arya S, Kumar VL. Inhibitory effect of extracts of latex of Calotropis procera against Candida albicans. A preliminary study. Indian J Pharmacol 2005;37(5):334-335.

[97] Nostro A, Germano, MP, D'Angelo V, Marino A, Cannatelli MA. Extraction methods and bioautography for evaluation of medicinal plant antimicrobial activity. Lett Appl Microbiol 2000;30(5):379-384.

[98] Ali SN, Kazmi SU, Akhtar N, Malik A. An Antitumor Cardenolide with Inhibitory Activity against Pseudomonas pseudomallei. Pak J Pharm Sci 1993; 6(1):61-66.

[99] Khalil A, Dababneh BF, Al-Gabbiesh AH. Antimicrobial activity against pathogenic microorganisms by extracts from herbal Jordanian plants. Journal of Food, Agriculture \& Environment 2009;7(2):103-106.

[100] Kuta FA. Antifungal effects of Calotropis procera stem bark on Epidermophyton flocosum and Trichophyton gypseum. Afr J Biotechnol 2008;7(13):2116-2118.

[101] Larhsini M, Oumoulid L, Lazrek HB, Wataleb S, Bousaid M, Bekkouche K, Jana M. Antibacterial activity of some Moroccan medicinal plants. Phytother Res 1999;15(3):250-252.

[102] Yesmin MN, Uddin SN, Mubassara S, Akond MA. Antioxidant and Antibacterial Activities of Calotropis procera Linn. AmericanEurasian J Agric \& Environ Sci 2008;4 (5):550-553.

[103] Kareem SO, Akpan I, Ojo OP. Antimicrobial Activities of Calotropis procera on Selected Pathogenic Microorganisms. African J Biomed Res 2008;11(1):105-110.

[104] Al-Qarawi AA, Mahmoud OM, Sobaih MA, Haroun EM, Adam SEI. A Preliminary Study on the Anthelmintic Activity of Calotropis procera Latex against Haemonchus contortus Infection in Najdi Sheep. Vet Res Commun 2001;25(1):61-70.

[105] Iqbal Z, Lateef M, Jabbar A, Muhammad G, Khan MN. Anthelmintic activity of Calotropis procera (Ait.) Ait. F. flowers in sheep. J Ethnopharmacol 2005; 102(2):256-261.

[106] Iwalewa EO, Elujoba AO, Olanrewaju A. In vitro spasmolytic effect of aqueous extract of Calotropis procera on Guinea-pig trachea smooth muscle chain. Fitoterapia 2005;76(2):250-253.

[107] Seddek ALS, Mahmoud ME, Shiina T, Hirayama H, Iwami M, Miyazawa S, Nikami H, Takewaki T, Shimizu Y. Extract from Calotropis procera latex activates murine macrophages. J Nat Med 2009;63(3):297-303.

[108] Dewan S, Sangraula H, Kumar VL. Preliminary studies on the analgesic activity of latex of Calotropis procera. J Ethnopharmacol 2000;73:307-311.

[109] Larhsini M, Markouk M, Jaouhari JT, Bekkouche K, Lazrek HB, Jana M. The antipyretic activity of some Moroccan medicinal plants. Phytother Res 2002;16:97-98.

[110] Ames BN, Shigenaga MK, Hagen TM. Oxidants, antioxidants, and the degenerative diseases of aging. Proc Natl Acad Sci USA 1993; 90:7915-7922.

[111] Ames BN. Dietary carcinogens and anticarcinogens: oxygen radicals and degenerative diseases. Science 1983; 221:256-1264.

[112] Gey KF. The antioxidant hypothesis of cardiovascular disease: epidemiology and mechanisms. Biochem Soc Trans 1990;18:10411045 .

[113] Smith MA, Perry G, Richey PL, Sayre LM, Anderson V, Beal, MF, Kowal N, Oxidative damage in Alzheimer's. Nature 1996;382:120-121

[114] De la Fuente M, Victor M. Antioxidants as modulators of immune function. Immunol Cell Biol 2000;78:49-54.

[115] Joshi R, Sharma A, Jat BL. Analysis of antioxidant activity in extracts of Calotropis procera (Ait.) R.Br. J Appl Biosci 2009;17:899-903. 
[116] Roy S, Sehgal R, Padhy BM, Kumar VL, Antioxidant and protective effect of latex of Calotropis procera against alloxan-induced diabetes in rats. J Ethnopharmacol 2005;102(3):470-473.

[117] Rasik M, Raghubir R, Gupta A, Shukla A, Dubey MP, Srivastava S, Jain HK, Kulshrestha DK, Healing potential of Calotropis procera on dermal wounds in Guinea pigs. J Ethnopharmacol 1999;68:261-266.

[118] Setty SR, Quereshi AA, Viswanath Swamy AHM, Patil T, Prakash T, Prabhu K, Gouda AV. Hepatoprotective activity of Calotropis procera flowers against paracetamol-induced hepatic injury in rats. Fitoterapia 2007;78:451-454.

[119] MueenAhmed KK, Ranab AC, Dixit VK. Effect of latex on isoproterenol induced myocardial infarction in albino rats. Phytomedicine 2004;11(4):327-330.

[120] Kumar VL, Roy S. Protective effect of latex of Calotropis procera in Freund's Complete Adjuvant induced monoarthritis. Phytother Res 2007;23(1):1-5.

[121] Turner RA. Screening Methods in Pharmacology. Academic Press, London 1965.

[122] Al-Rajhy DH, Alahmed AM, Hussein HI, Kheir SM. Acaricidal effects of cardiac glycosides, azadirachtin and neem oil against the camel tick, Hyalomma dromedarii (Acari: Ixodidae). Pest Manag Sci 2003;59(11):1250-1254.

[123] Soares PM, Lima SR, Matos SG, Andrade MM, Patrocinio MCA, De Freitas CDT et al. Antinociceptive activity of Calotropis procera latex in mice. J Ethnopharmacol 2005;99(1):125-129.

[124] Basu A, Sen T, Pal S, Mascolo N, Capasso F, Nag AK, Studies on the Antiulcer Activity of the Chloroform Fraction of Calotropis procera Root Extract. Phytother Res 1996;11(2):163-165.

[125] Kamath JV, Rana AC. Preliminary study on anti-fertility activity of Calotropis procera roots in female rats. Fitoterapia 2002;73(2):111-115.

[126] Mahmoud OM, Haroun EM, Sobaih MA, Omer OH, Adam SEI. Comparative efficacy of Calotropis procera latex and sulfadimidine against experimentally-induced Eimeria ovinoidalis infection in Najdi lambs. Small Ruminant Res 2001;42(2):135140 .

[127] Sharma BM. Root systems of some desert plants in Churu, Rajasthan. Indian Forester 1968;94(3):240-246.

[128] Rahman MA, Wilcock CC. A taxonomic revision of Calotropis (Asclepiadaceae). Nord J Bot 1991;11(3):301-308.

[129] Weber J. A natural control of Dutch elm disease. Nature 1981;292:449-451.

[130] Shiomi HF, Silva HSA, De Melo IS, Nunes FV, Bettiol W. Bioprospecting endophytic bacteria for biological control of coffee leaf rust. Sci Agric 2006; 63(1):32-39.

[131] Malinowski DP, Belesky DP. Ecological importance of Neotyphodium sp. Grass endophytes in agroecosystems. Grassland Science 2006;52(1):23-28.

[132] Strobel GA. Microbial gifts from rain forests. Can J Plant Pathol 2002;24:14-20.

[133] Khan R, Shahzad S, Choudhary MI, Khan SA, Ahmad A. Biodiversity of the Endophytic Fungi Isolated from Calotropis Procera (Ait.) R. Br. Pak J Bot 2007;39(6):2233-2239.

[134] Urbanek HJ, Zalewska S, Borowińsk A. Isolation and properties of extracellular cellulose hemicellulase complex of Phoma hibernica. Arch Microbiol 1998;118(3):265-269.

[135] Frohlich J, Hyde KJD. Biodiversity of palm fungi in the tropics: are global fungal diversity estimated realistic? Biodiversity Conserv 1999;8:977-1004.

[136] Suryanarayanan TS, Venkatesan G, Murali TS. Endophytic fungal communities in leaves of tropical forest trees: Diversity and distribution patterns. Curr Sci 2003;85(4):489-492.

[137] Bokhary HA, Al-Sohaibany S, Al-Sadoon QH, Parvez S. Fungi associated with Calotropis procera and Capparis spinosa leaves. J King Saud Univ 2000;12(1):11-23.

[138] Mahran GH Rizkallah MM Saber AH. "A Phytochemical study of Calotropis procera" (Ait.) R.Br. Growing in Egypt. Bull Fac Pharm Cairo Univ (1971); 10:1.

Table-1. Phytochemicals from Calotropis procera

\begin{tabular}{|c|c|c|c|}
\hline S. No. & Name of compound & Plant parts & References \\
\hline 1) & B-Amyrin & Root bark & Anjaneyulu et al, \\
\hline 2) & $\alpha$-Amyrin & Root bark & Anjaneyulu et al, [41] \\
\hline 3) & Taraxasterol & Root bark & Anjaneyulu et al, [41] \\
\hline 4) & $\Psi$-Taraxasterol & Root bark & Anjaneyulu et al, [41] \\
\hline 5) & B-Sitosterol & Root bark & Anjaneyulu et al, [41] \\
\hline 6) & Taraxasteryl acetate & Root bark & Anjaneyulu et al, [41] \\
\hline 7) & Taraxasteryl benzoate & Root bark & Anjaneyulu et al, [41] \\
\hline 8) & $\alpha$-Amyrin benzoate & Root bark & Anjaneyulu et al, [41] \\
\hline 9) & ß-Amyrin benzoate & Root bark & Anjaneyulu et al, [41] \\
\hline 10) & B-Amyrin acetate & Root bark & Anjaneyulu et al, [41] \\
\hline 11) & Acetic acid & Root bark & Anjaneyulu et al, [41] \\
\hline 12) & Isovaleric acid & Root bark & Anjaneyulu et al, [41] \\
\hline 13) & Taraxasterol isovalerate & Leaves & Anjaneyulu et al, [41] \\
\hline 14) & Benzoyllineolone & Root bark & Chandler et al, [42] \\
\hline 15) & Benzoylisolineolone & Root bark & Chandler et al, [42] \\
\hline 16) & Uzarigenin & Latex & Brueschweiler et al, [43] \\
\hline 17) & Syriogenin & Latex & Brueschweiler et al, [43] \\
\hline 18) & Proceroside & Latex & Brueschweiler et al, [43] \\
\hline 19) & Calotropin & Leaves & Malik et al, [8] \\
\hline 20) & Calotropagenin & Leaves & Malik et al,[8] \\
\hline 21) & Calotoxin & Latex & Maharan et al, [138] \\
\hline
\end{tabular}


Therapeutic Potential of Calotropis procera: A giant milkweed

\begin{tabular}{|l|l|l|l|}
\hline 22$)$ & Uscharin & Latex & Maharan et al, [138] \\
\hline 23$)$ & Uscharidin & Latex & Maharan et al, [138] \\
\hline 24$)$ & Choline & Latex & Maharan et al, [138] \\
\hline 25$)$ & Procerain & Latex & Dubey and Jagannadham, [48] \\
\hline 26$)$ & Isorhamnetin-3-O-rutinoside & Leaves & Gallegos-Olea et al, [50] \\
\hline 27$)$ & isorhamnetin-3-O-robinobioside & Leaves & Gallegos-Olea et al, [50] \\
\hline 28$)$ & Procerursenyl acetate & Roots & Alam and Ali, [51] \\
\hline 29$)$ & Proceranol & Roots & Alam and Ali, [51] \\
\hline 30$)$ & D-glucose & Leaves & Bhaskar and Ajay, [44] \\
\hline 31$)$ & D-arabinose & Leaves & Bhaskar and Ajay, [44] \\
\hline 32$)$ & D-glucosamine & Leaves & Bhaskar and Ajay, [44] \\
\hline 33$)$ & $\alpha$-rhamnose & Leaves & Bhaskar and Ajay, [44] \\
\hline
\end{tabular}

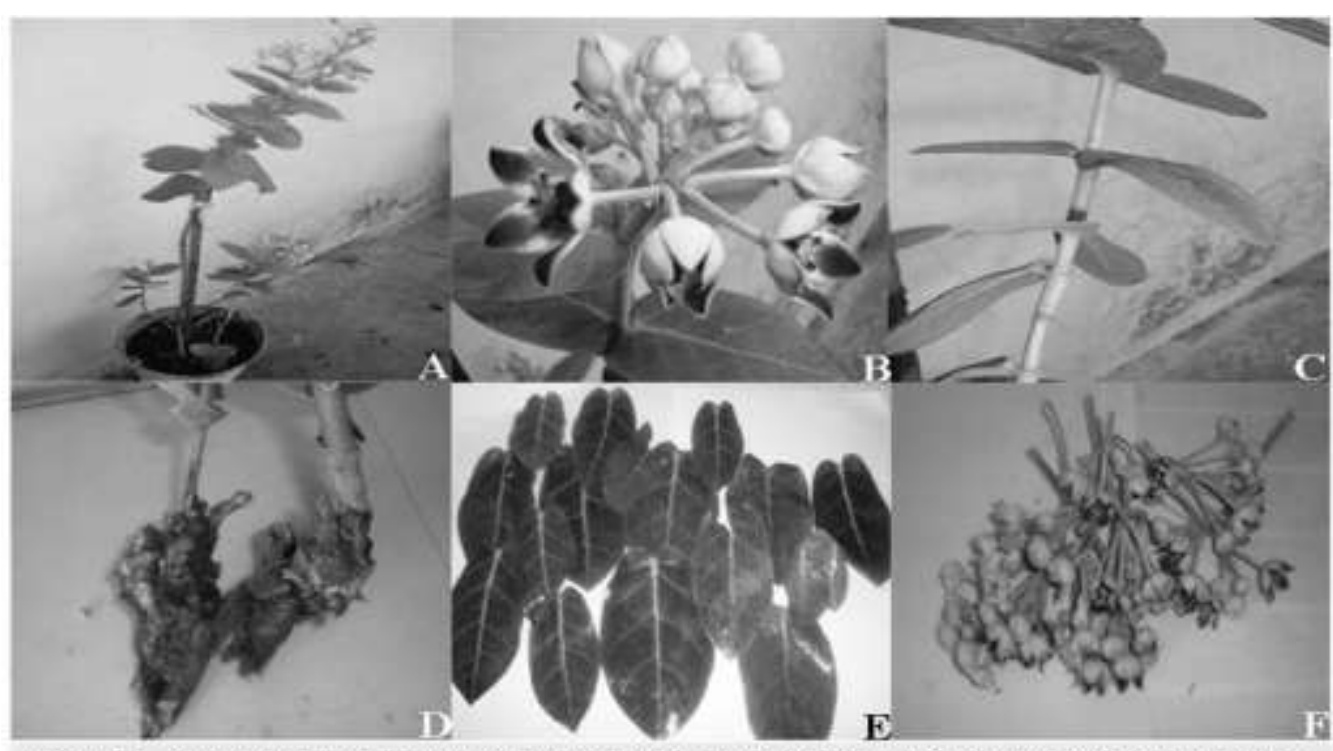

Figure 1. Calornopis procema (A) Plant growing in herbal garden (B) Flowers with inflorescence (C) Stem of C. Procera (D) Roots of C. Procera (E) Leaves of C. Procera (F) Flower: of $\mathrm{C}$ Procerc

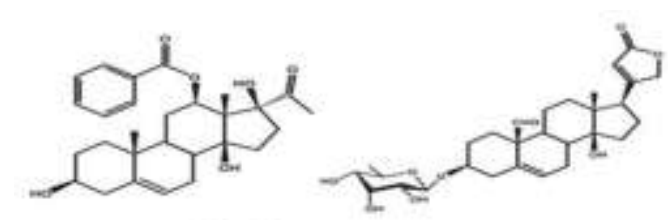

1. Calotropon

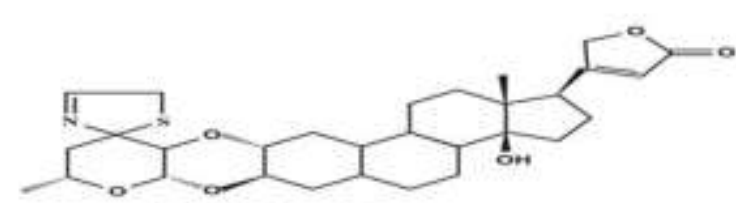

11. Catotropin
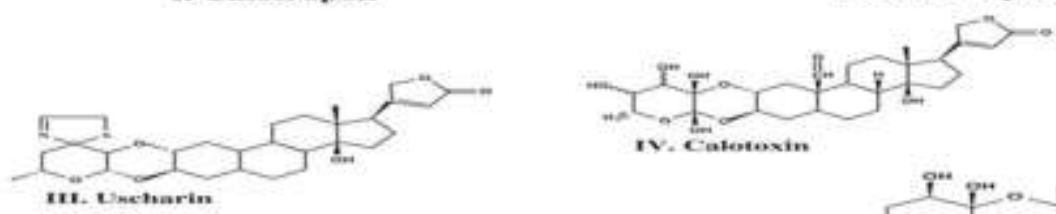

wi. Unetharin

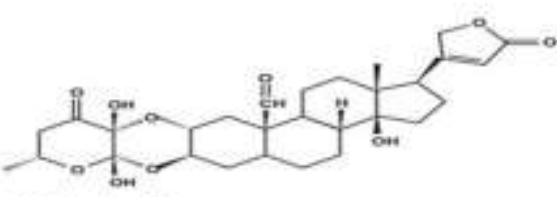

VI. Useharidin

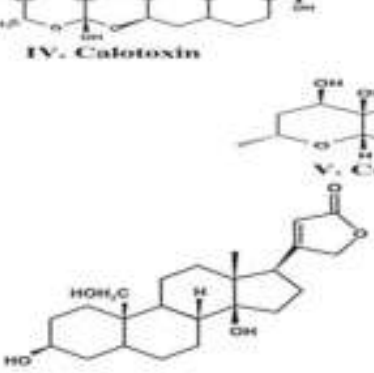

vII. Caroglaucigenin

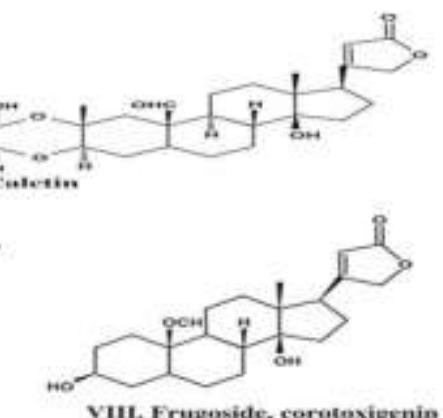

Figure 2. Phytochemical constituents of Calotropis procera 

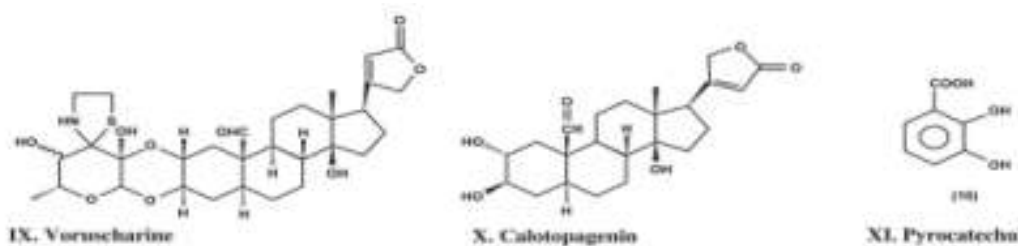

IX, Vermecharine

X. Calotejaernin

X1. Pyrecatexthie adiet
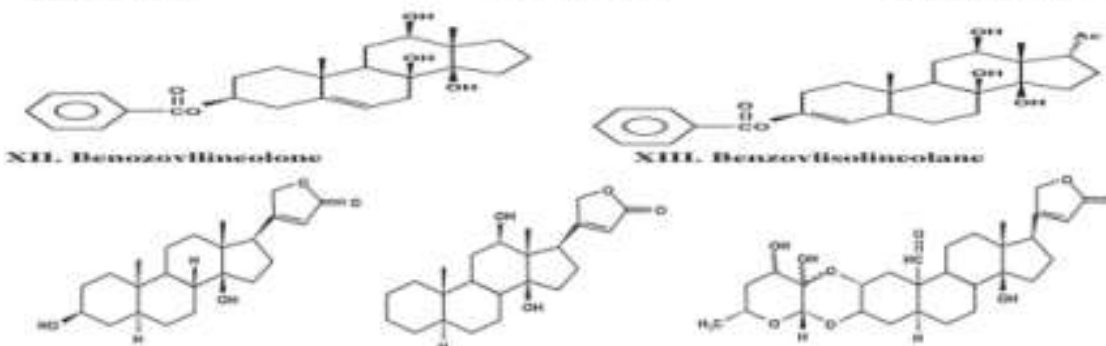

viv. Varternin

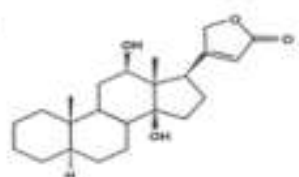

XV. Syringernim

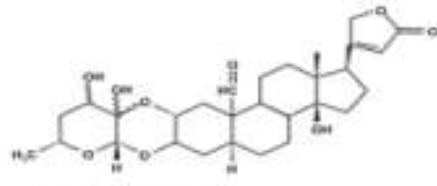

xve. monermite

Figure 3. Phytochemical constituents of Calorropis procera (continue)

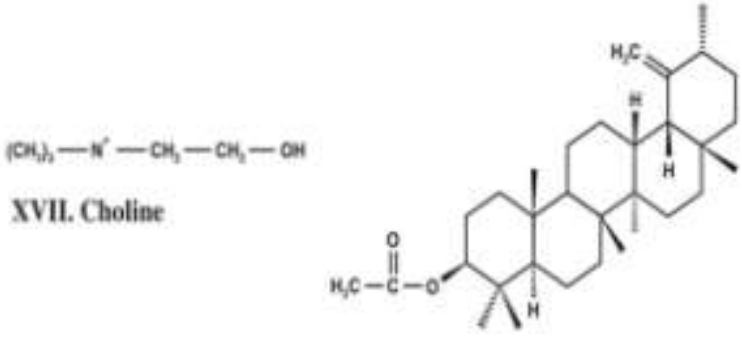

XVIII. Calotropenyl acetate

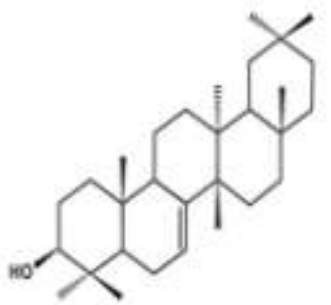

XI. Multifloresol

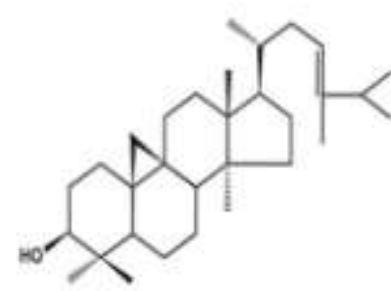

XXI. Cylosadol

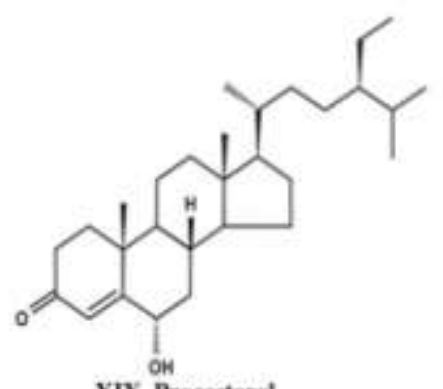

XIX. Procesterol<smiles>CC(C/C=C/C(C)(C)O)C1CCC2(C)C1CCC1(C)C2CCC2C(C)(C)C(O)CCC21C</smiles>

XXIL. Cyloart-23-ene-3B-25-diol

Figure 4. Phytochemical constituents of Calotropis procera (continue)

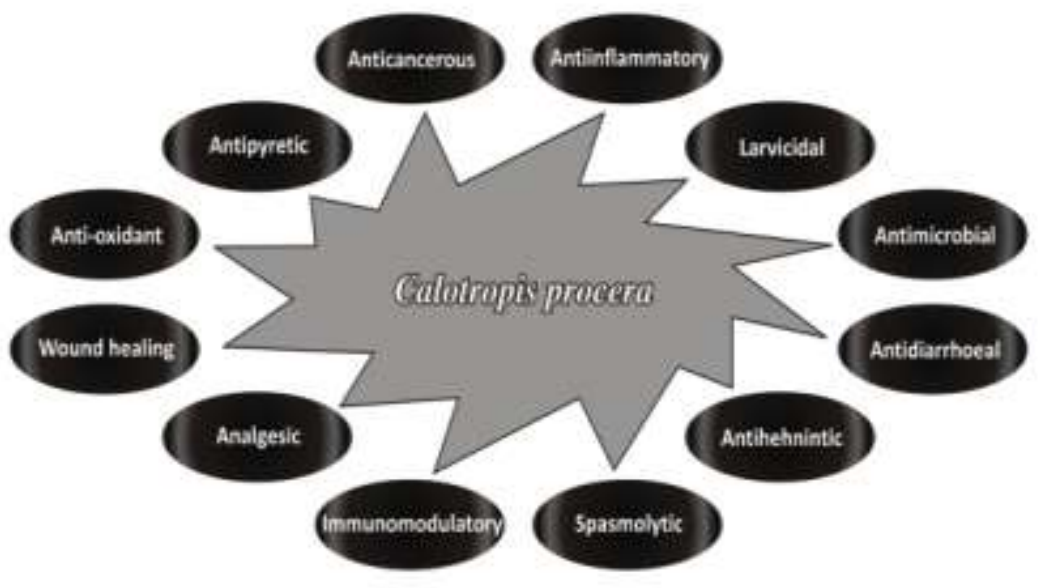

Figures. Medicialal applications of Caletropis procera 